\title{
Carcass composition and meat characteristics of Pekin ducks in relation to age at slaughter and level of maize distiller's dried grains with solubles in diets*
}

\author{
A. Kowalczyk ${ }^{1}$, E. Lukaszewicz ${ }^{1,3}$, M. Adamski ${ }^{1,2}$ and J. Kuźniacka ${ }^{2}$ \\ ${ }^{l}$ Wroclaw University of Environmental and Life Sciences, Institute of Animal Breeding, \\ Division of Poultry Breeding \\ Chetmońskiego 38c, 51-630 Wroctaw, Poland \\ ${ }^{2}$ University of Technology and Life Sciences in Bydgoszcz, Department of Poultry Breeding \\ Mazowiecka 28, 85-084 Bydgoszcz, Poland
}

(Received 4 July 2011; revised version 27 October 2011; accepted 12 March 2012)

\begin{abstract}
The effect of the level of maize distiller's dried grains with solubles (DDGS) in diets for ducks and duration of the fattening period on feed efficiency, body weight, carcass and meat quality was studied. One hundred and sixty commercial Pekin ducklings were divided randomly into four groups (four replicates, each). From 1 to 21 days of age all birds received the same commercial feed, then from day 22 to 56 the ducks were fed with a diet containing one of four levels of DDGS (\%): 0 (control), 15, 25 or 30. All ducks were weighed individually at 1, 21, 49 and 56 days of age and feed intake and feed efficiency were calculated. At 49 and 56 days of rearing, 10 birds with body weights close to the average weight for the group were chosen from each group, slaughtered and the following parameters were evaluated: weight of eviscerated carcass with neck, neck without skin, wings with skin, breast and leg muscle, edible giblets (heart, liver, gizzard), skin with subcutaneous fat, abdominal fat, remainder of carcass, as well as the physical and chemical characteristics of breast meat. Inclusion of maize DDGS in amounts up to $25 \%$ in the diet of ducks from day 22 of rearing had no adverse effect on the variables studied, regardless of age at slaughter. Moreover, it allowed decreasing the soyabean meal and wheat contents from 18.0 and $41.6 \%$ in the control feed to 10.0 and $24.1 \%$ in the $25 \%$ DDGS feed, respectively.
\end{abstract}

KEY WORDS: DDGS, Pekin ducks, body weight, feed efficiency, carcass quality, breast meat

\footnotetext{
* Supported by the Ministry of Science and Higher Education, Project No. R12 05903

${ }^{3}$ Corresponding author: e-mail: ewa.lukaszewicz@up.wroc.pl
} 


\section{INTRODUCTION}

Although duck production and duck meat consumption in Poland and other European countries are not as popular as chicken or turkey, increasing interest in alternative meat can be observed in the last decades. Also in Asia, the leading duck producer, a changing food consumption pattern has been noticed. As in many developing countries, consumers have become interested in better-quality food products such as animal-protein-rich meat, therefore, an increase in meat-type duck production can be expected. In ducks, as in other animal species used for meat production, a decrease in feeding costs and utilization of available by-products are always current and very important goals. It has already been reported that maize dried distillers grains with solubles (DDGS) can be satisfactorily used in diets for broilers (Lumpkins et al., 2004; Wang et al., 2007; Corzo et al., 2009), turkeys (Roberson, 2003), laying hens (Lumpkins et al., 2005; Roberson et al., 2005; Świątkiewicz and Koreleski, 2006), and pigs (Whitney et al., 2006), but there is no information related to ducks. It is interesting that ducks are very sensitive to any nutrient deficiency, improper feed formulation or feed contamination with various unwholesome substances and are considered good 'bioindicators' of feed quality. DDGS can be a valuable feed component for poultry due to its high concentration of protein, amino acids, available phosphorus, xanthophylls and many biologically active substances (Świątkiewicz and Koreleski, 2008), however, proper utilization of DDGS in poultry diets requires appropriate formulation of feed mixtures designated for particular bird species and type of production (Roberson et al., 2005; Wang et al., 2007).

In the present study, the effect of DDGS inclusion and age at slaughter on growth performance and breast meat quality of Pekin ducks was investigated.

\section{MATERIAL AND METHODS}

In total, 160 newly hatched Pekin ducks (Anas platyrhynchos f. domestica, strain P55) were divided randomly into four groups (40 birds each) and four replicates (10 birds each). From day 1 to 21 of age, all birds received the same commercial feed, then from days 22 to 49-56, the ducks were fed a diet containing of one of four levels of DDGS: $0 \%$ (control), 15, 25 or 30\%.

The birds were raised on deep litter under controlled environmental conditions. Feeds (crumbled) and water were available ad libitum. Pens of $1.2 \times 2.0 \mathrm{~m}\left(2.4 \mathrm{~m}^{2}\right)$ were provided per replicate (10 birds).

All ducks were weighed individually at 1, 21, 49 and 56 days of age. The amounts of administered feed and refusal remainders were weighed in every group 
and replicate, so feed intake and feed efficiency were calculated.

At 49 and 56 days of rearing, 10 birds of a body weight close to the group average were selected from every group, slaughtered in a waterfowl slaughter house and, after $24 \mathrm{~h}$ of cooling at $+4^{\circ} \mathrm{C}$, the carcasses were used for further analysis (Ziołecki and Doruchowski, 1989). The following parameters were evaluated (in \%, in relation to live body weight and weight of eviscerated carcass with neck): eviscerated carcass with neck, neck without skin, wings with skin, breast and leg muscle, edible giblets (heart, liver, gizzard), skin with subcutaneous fat, abdominal fat and remainder of carcass. Next, the right breast muscle was minced, homogenized and subjected to hygroscopicity (in \%), by a modified method of Grau and Hamm (1952) and chemical analysis AOAC, 1995. The $\mathrm{pH}$ was measured in the left breast muscle (with 0.01 accuracy) $15 \mathrm{~min}\left(\mathrm{pH}_{15}\right)$ after slaughter and after $24 \mathrm{~h}\left(\mathrm{pH}_{24}\right)$ of cooling at $4^{\circ} \mathrm{C}$, using a spear tip electrode connected to a $\mathrm{pH}$-meter (CP-401, ELMETRON). The electrode was placed at an angle of $45^{\circ}$, halfway through the muscle. Meat colour measurements (values: $L^{*}$, $\left.a^{*}, b^{*}\right)$ were performed on the inner surface of the left breast muscle, after $24 \mathrm{~h}$ of cooling, using a Minolta CR- 400/410 apparatus.

The chemical composition of DDGS determined at the facilities of an ethanol fuel plant in Murowana Goślina (Poland) was as follows, g/kg: dry matter 93.06, crude protein 27.33 , crude ash 5.67 , crude fibre 7.25 , fat 11.74 and amino acids (in g/100 g protein): lysine 2.49, methionine + cystine 2.98, threonine 3.95, tryptophan 3.64. The chemical composition of the mixtures used as duck feed is shown in Table 1.

Table 1. Chemical composition of the feeds used in the experiment for commercial Pekin ducks strain P55

\begin{tabular}{lcrrrr}
\hline & & \multicolumn{3}{c}{ Feeding groups from 22 to 49-56 day } \\
Item & Feed supplied from & \multicolumn{4}{c}{ of rearing } \\
\cline { 3 - 6 } & 1 to 21 day of rearing & \multicolumn{4}{c}{ DDGS, \% } \\
\cline { 3 - 6 } & & 12.25 & 12.31 & 12.38 & 12.33 \\
\hline $\mathrm{ME}_{\mathrm{N}}, \mathrm{MJ} / \mathrm{kg}$ & 11.84 & 174.6 & 178.6 & 180.3 & 177.1 \\
Crude protein, $\mathrm{g} / \mathrm{kg}$ & 200.20 & 31.05 & 35.53 & 38.46 & 39.82 \\
Crude fibre, $\mathrm{g} / \mathrm{kg}$ & 30.30 & 9.38 & 9.38 & 9.23 & 9.30 \\
Lysine, $\mathrm{g} / \mathrm{kg}$ & 10.75 & 7.41 & 7.48 & 7.64 & 7.47 \\
Methionine $+\mathrm{gystine}, \mathrm{g} / \mathrm{kg}$ & 8.50 & 2.04 & 2.01 & 2.00 & 1.94 \\
Tryptophan, $\mathrm{g} / \mathrm{kg}$ & 2.41 & 6.11 & 6.36 & 6.53 & 6.41 \\
Threonine, $\mathrm{g} / \mathrm{kg}$ & 7.07 & 3.96 & 4.23 & 3.98 & 4.05 \\
$\mathrm{P}$ available, $\mathrm{g} / \mathrm{kg}$ & 5.53 & 8.88 & 8.56 & 8.74 & 8.76 \\
Ca, g/kg & 9.96 & 100.0 & 86.16 & 77.95 & 72.05 \\
Relative costs of $1 \mathrm{t}$ feed, \% & - & & &
\end{tabular}

${ }^{1}$ feeds were standardized according to recommendations for commercial Pekin ducks (Smulikowska and Rutkowski, 2005) 
All diets (produced by a commercial feed company) were formulated in order to ensure uniformity of chemical composition and nutritive value, and standardized according to recommendations for commercial ducks (Smulikowska and Rutkowski, 2005).

The experiment was approved by the II Local Ethics Commission for Experiments Performed on Animals.

\section{Statistical analysis}

Obtained data were verified statistically by ANOVA, while the significance of differences, by the Tukey test (Statistica, version 7.1, StatSoft, Inc. Data analysis software system, 2007).

\section{RESULTS}

The average body weight of one-day-old ducklings and after 21 days of rearing, was similar in all groups (Table 2). On day 49 of rearing, the $30 \%$ DDGS inclusion decreased body weight $(\mathrm{BW})$ significantly $(\mathrm{P}<0.05)$ compared with the control and $15 \%$ DDGS group, however, after a further week, birds from the experimental groups compensated their body weights, and no significant differences were observed between any of the dietary treatments.

Table 2. Effect of maize distiller's dried grains with solubles (DDGS) level on live body weight (g) of Pekin ducks strain P55 ( $\mathrm{n}=40$ up to 49 day; $\mathrm{n}=30$ at 56 day of age; means \pm SD)

\begin{tabular}{lcrrc}
\hline Feeding groups & \multicolumn{4}{c}{ Age of birds, days } \\
\cline { 2 - 5 } DDGS, \% & \multicolumn{1}{c}{21} & \multicolumn{1}{c}{49} & 56 \\
\hline 0 (control) & $53.8 \pm 4.2$ & $997.5 \pm 191.5$ & $3079.5^{\mathrm{a}} \pm 275.2$ & $3303.4 \pm 308.8$ \\
15 & $52.9 \pm 4.9$ & $1093.4 \pm 159.9$ & $3069.4^{\mathrm{a}} \pm 260.6$ & $3284.6 \pm 227.5$ \\
25 & $54.2 \pm 3.0$ & $1102.6 \pm 156.4$ & $3016.7^{\mathrm{a}, \mathrm{b}} \pm 206.9$ & $3312.1 \pm 278.6$ \\
30 & $53.4 \pm 4.8$ & $1055.3 \pm 197.9$ & $2934.2^{\mathrm{b}} \pm 256.6$ & $3232.1 \pm 300.7$ \\
\hline
\end{tabular}

${ }^{1}$ mean values in columns with different letters differ significantly ${ }^{\mathrm{a}, \mathrm{b}} \mathrm{P}<0.05$

The average feed intake (FI) per bird (2128-2298 g) and feed conversion ratio (FCR) $(2140 \mathrm{~g} / \mathrm{kg} \mathrm{BW})$ during the first 21 days (the birds received the same feed) were similar, indicating the good quality and uniformity of birds, as well as proper rearing conditions (Table 3). The inclusion of DDGS from day 22 of rearing differentiated both FI and FCR. After 49 days of rearing, the ducks with the lowest FI $(8.03 \mathrm{~kg})$ and the most profitable FCR $(2710 \mathrm{~g} / \mathrm{kg} \mathrm{BW})$ were found in the $25 \%$ DDGS group, and both traits were significantly $(\mathrm{P}<0.05)$ lower compared with the remaining groups. Similar observations were noted for 56-day-old ducks (Table 3). 
Table 3. Effect of maize distiller's dried grains with solubles (DDGS) level on feed intake and feed conversion rate of Pekin ducks strain P55 (means \pm SD)

\begin{tabular}{lccccccc}
\hline $\begin{array}{l}\text { Feeding } \\
\text { groups, }\end{array}$ & \multicolumn{3}{c}{$\begin{array}{c}\text { Feed intake during rearing period } \\
\text { g/bird/day }\end{array}$} & & \multicolumn{3}{c}{$\begin{array}{c}\text { Feed conversion ratio } \\
\mathrm{g} / \mathrm{kg} \text { body weight } / \text { day }\end{array}$} \\
\cline { 2 - 4 } \cline { 6 - 8 } DDGS \% & $1-21$ & $1-49$ & $1-56$ & & $1-21$ & $1-49$ & $1-56$ \\
\hline 0 (control) & $2128 \pm 93$ & $9721^{\mathbf{a}} \pm 643$ & $13505^{\mathbf{a}, \mathbf{b}} \pm 1960$ & & 2140 & $3145^{\mathbf{a}}$ & $4040^{\mathbf{a}}$ \\
15 & $2296 \pm 108$ & $10639^{\mathbf{a}} \pm 1010$ & $15618^{\mathbf{a}} \pm 2432$ & & 2090 & $3465^{\mathbf{a}}$ & $4750^{\mathbf{b}}$ \\
25 & $2288 \pm 143$ & $8030^{\mathbf{b}} \pm 964$ & $11902^{\mathbf{b}} \pm 2060$ & & 2160 & $2710^{\mathbf{b}}$ & $3775^{\mathbf{a}}$ \\
30 & $2207 \pm 179$ & $9246^{\mathbf{a}, \mathbf{b}} \pm 988$ & $14347^{\mathbf{a}} \pm 1800$ & & 2100 & $3225^{\mathbf{a}}$ & $4450^{\mathbf{b}}$ \\
\hline
\end{tabular}

${ }^{1}$ mean values in columns with different letters differ significantly a,b $\mathrm{P}<0.05$

On day 49 of age, the highest average carcass weight with neck (2025 g) was observed in the $15 \%$ DDGS group and was higher $(\mathrm{P}<0.05)$ than in the $30 \%$ DDGS group (Table 4) however, the DDGS inclusion level did not affect slaughter yield. The analysis of carcass tissue composition showed that in groups 25 and $30 \%$ DDGS, total muscle weight was lower $(\mathrm{P}<0.05)$ than in the control and 15\% DDGS groups, but only the amount of breast muscle was affected. Higher amounts of skin with subcutaneous fat and abdominal fat in ducks fed 15\% DDGS were found. These values were significantly $(\mathrm{P}<0.05)$ higher than in the $25 \%$ DDGS group (for skin with subcutaneous fat), and in all remaining groups (in relation to abdominal fat content). Other evaluated carcass parameters (neck without skin, wings with skin, edible giblets, and remainder of carcass) were not affected significantly by the DDGS inclusion level (Table 4).

As could be expected, live body weight, as well as the carcass with neck, total muscle, and breast muscle weights of 56-day-old ducks were significantly $(\mathrm{P}<0.05)$ higher compared with one-week-younger birds, however, surprisingly leg muscle content was not significantly affected by the length of the rearing period $(\mathrm{P}<0.05)$. A higher content of skin with subcutaneous fat and abdominal fat was found in older birds from the control and 15\% DDGS group when compared with the 25 and $30 \%$ DDGS groups.

In 56-day-old ducks, the highest average BW and carcass weight was noted in the $25 \%$ DDGS group, and both values were higher $(\mathrm{P}<0.05)$ compared with the $30 \%$ group (Table 4 ). Although inclusion of $30 \%$ DDGS in the diet significantly decreased $(\mathrm{P}<0.05)$ slaughter yield compared with the 15\% DDGS group, the amount of skin with subcutaneous fat and abdominal fat was also lower $(\mathrm{P}<0.05)$ in relation to the control and other experimental groups, while total muscle, breast and leg muscle weights were not affected (Table 4). In the other groups, regardless of the length of rearing, slaughter yield was not affected by the DDGS inclusion level. The proportions of neck without skin, wings with skin, edible giblets and remainder of the carcass were not affected by dietary DDGS levels (Table 4). Significant $(\mathrm{P}<0.05)$ differences in the above carcass characteristics caused by the 


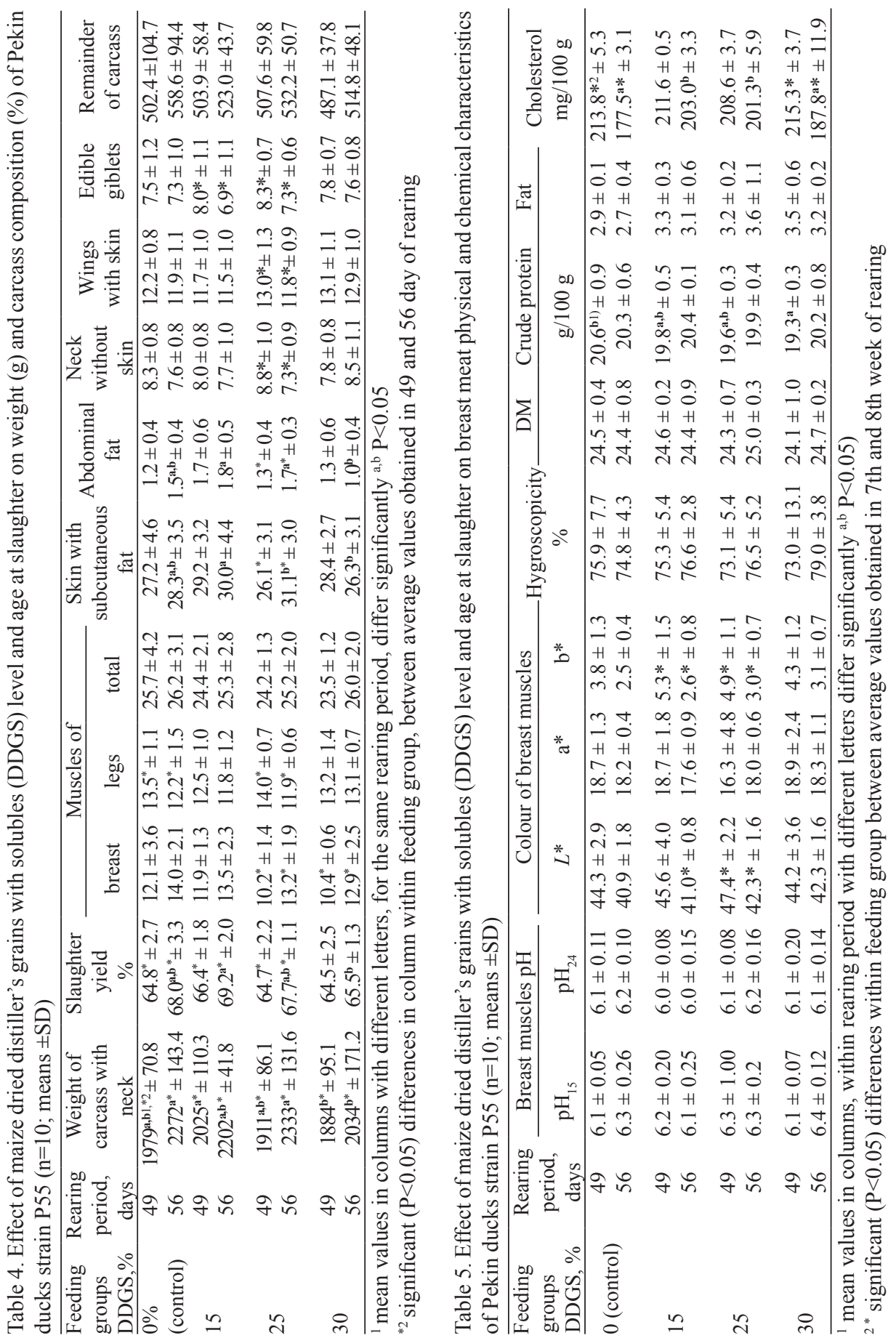


length of the rearing period were observed only in relation to the weight of wings with skin in the control and 25\% DDGS groups.

Partial replacement of dietary soyabean meal and wheat by DDGS did not significantly affect $(\mathrm{P}>0.05)$ any of the physical breast muscle characteristics $\left(\mathrm{pH}_{15}, \mathrm{pH}_{24}\right.$, colour $-L^{*}, \mathrm{a}^{*}, \mathrm{~b}^{*}$, and hygroscopicity) (Table 5). Only the meat of 49-day-old ducks from the 15 and 25\% DDGS groups was darker $\left(L^{*}\right)$ and had a higher yellowness $\left(b^{*}\right)$ in relation to the meat of the older birds.

The dry matter and fat contents were not affected by either the DDGS level or rearing period. Similarly, the crude protein in 56-day-old birds, and the cholesterol content in 49-day-old ducks were not affected by DDGS levels (Table 5). Adding $30 \%$ DDGS caused a significant $(\mathrm{P}<0.05)$ decrease in crude protein content when compared with the control group ( $19.3 \mathrm{vs} 20.6 \mathrm{mg} / 100 \mathrm{~g})$. The cholesterol content was generally lower in the meat of older ducks, and in the 15 and $25 \%$ DDGS groups, higher $(\mathrm{P}<0.05)$ than in the control and 30\% DDGS groups (Table 5).

\section{DISCUSSION}

The experiments carried out by Roberson (2003) and Lumpkins et al. (2004) on DDGS utilization in poultry feeding revealed that levels over $15 \%$ in laying hens and $10 \%$ in commercial turkeys significantly decreased body weight. Our results showed that in intensively reared Pekin ducks, DDGS is a good alternative feedstuff and can be applied in a higher level than in other poultry species. For poultry producers, lowering feeding costs is a priority. Our data showed that as the DDGS level increases, the costs of 1 ton feed decline (by up to $28 \%$ compared with commercial feed when $30 \%$ DDGS was included), which is very important from an economic point of view. Adding DDGS to duck diets allowed decreasing the soyabean content from $18 \%$ in the control feed to $13 \%$ in $15 \%$ DDGS, $10 \%$ in $25 \%$ DDGS, and $7 \%$ in $30 \%$ DDGS and the content of wheat from 41.6 to $32.5 \%, 23.7$ and $24.1 \%$, respectively. In the group fed 25\% DDGS, both 49- and 56 -week-old birds (relative production costs of 1 ton constituted $78 \%$ of that using commercial feed), the FCR was significantly $(\mathrm{P}<0.05)$ better than in the remaining groups. Bernacki et al. (2006) obtained a FCR of $3.37 \mathrm{~kg}$ per kg BW for 49-dayold, and $3.81 \mathrm{~kg} / \mathrm{kg} \mathrm{BW}$ for 56-day-old Pekin AP57 and PP54 hybrids, which is worse than our results. In an experiment on chicken broilers, Wang et al. (2007) concluded that inclusion of up to $25 \%$ DDGS had no adverse effect on growth rate, however, FCR was poorer as compared with the control group fed commercial feeds. Thus, as with any ingredient, the feed with a new component (DDGS in our case) should be reviewed by a quality control programme prior to large scale use, which will allow avoiding any nutritional problems and deficiencies of any basic 
nutrients, while permitting the production of good quality commercial ducks at lower costs. In our experiment, inclusion of DDGS at a level of $25 \%$ decreased the feeding costs per bird during 56 days of rearing.

Although after 49 days of rearing the average body weight of ducks fed $30 \%$ DDGS was lower $(\mathrm{P}<0.05)$ compared with the control and 15\% DDGS groups, in 56-day-old birds, no significant differences in body weight were observed. Live body weights obtained in all 49-day-old groups were higher compared with 2975 $\mathrm{g}$ for Pekin hybrids AP57 and PP54 obtained by Bernacki et al. (2006), Pekin pure strain A55-2943 g (Mazanowski and Książkiewicz, 2004) and $2887 \mathrm{~g}$ (Adamski et al., 2005), fed commercial feeds recommended for slaughter ducks. Also, after 56 days of rearing, the average live body weights of the experimental and control group were higher than the $3014 \mathrm{~g}$ reported by Bernacki et al. (2006) for Pekin hybrids.

In relation to the control group, the weight of the carcass with neck of 49-day-old ducks was not affected by dietary DDGS and was the highest in the 15\% DDGS group. Regardless of the DDGS level, the results obtained in our experiment were better than for the Pekin hybrids AP57 (1872 g) and PP54 (1821 g) evaluated by Bernacki et al. (2006) and of pure strains P66 (1813 g) and P77 (1887 g) (Kokoszyński and Korytkowska, 2005).

The slaughter yield of 49-day-old ducks from the control group and groups fed 15 and 25\% DDGS was significantly lower $(\mathrm{P}<0.05)$ compared with Pekin hybrids AP57 (68.2\%) and PP54 (68.9\%) (Bernacki et al., 2006), but similar to the $66.0 \%$ obtained by Mazanowski and Książkiewicz (2004) for P55. Despite the lower slaughter yield, the average proportion of total muscle was not significantly affected by either age at slaughter or DDGS level, and was comparable to Pekin strain P66 (25.7\%) (Witkiewicz et al., 2006) and hybrid PP54 (25.1\%) (Bernacki et al., 2006).

The proportion of skin with subcutaneous fat was similar to the $29.0 \%$ (Mazanowski and Książkiewicz, 2004) found in P55, and 29.7\% in Pekin strain P66 (Kokoszyński and Korytkowska, 2005). The amount of skin with subcutaneous fat increased only in the carcasses from 56-day-old groups fed 25 and 15\% DDGS diets.

Poultry producers are interested in minimizing production costs, while meat consumers are particularly interested in the nutritional value of animal products (Suchý et al., 2002). Chemical composition and physical traits of meat are crucial as far as technological properties and sensory quality are concerned, while meat colour contributes significantly to the consumer's choice. In our experiment, neither including DDGS at levels of $15-30 \%$ in duck diets nor the length of the rearing period significantly affected $(\mathrm{P}>0.05)$ the water contents, $\mathrm{pH}$, or colour of the breast muscles. In contrast to Chartrin et al. (2006), who claimed that muscles 
containing a high lipid level are paler and have a greater yellow intensity, we observed no effect of fat content on meat colour. Meat lightness $\left(L^{*}\right)$ of Pekin ducks strain P55 was much higher than evaluated in Turkish Pekin by Lacin et al. (2008) (33.06).

Similarly to the physical traits, the dry matter and fat contents in breast meat were not affected by either the DDGS level or the rearing period. The amount of dry matter was comparable to the results described by Wołoszyn et al. (2006) for strains P66 an A55, however, fat content was much higher than in paternal strains A44 and A55 (1.8\%) evaluated by Mazanowski et al. (2003) or hybrid PP54 (2.7\%) and AP57 (2.3\%) (Bernacki et al., 2006). It should be emphasized that due to the high percentage of red fibres in duck muscles, their metabolism is higher when compared with chicken or turkeys muscles, and lipids constitute an important component of duck meat (Baeza, 2006).

Although all of the diets used in this experiment were formulated to be of the same nutritive value, some differences in live body weight, FI and FCR were observed, depending on the amount of DDGS. We can speculate that these differences could have resulted from the lower availability of lysine supplied in DDGS or insufficient level of valine due to the replacement of soyabean meal and wheat. Lysine and sulphur amino acids exhibit specific effects on carcass composition. The lysine requirement for gain is lower than the requirement for FCR and percentage of breast meat, being the highest for the lowest percentage of abdominal fat (Leclercq, 1998). Similar relationships were observed for valine and threonine. On the other hand, the lack of significant differences in meat characteristics of ducks fed with $30 \%$ DDGS point to their wide feeding tolerance to feed components.

\section{CONCLUSIONS}

The results from this study appear very promising for Pekin duck meat producers. They show that maize distiller's dried grain with solubles (DDGS) included at levels up to $25 \%$ is a good alternative feedstuff for efficient intensive duck feeding. Based on body weight, feed intake, feed conversion ratio, carcass weight, slaughter yield, proportion of total muscle, and skin with subcutaneous fat in 49- and 56-day-old Pekin ducks, we can conclude that including up to $25 \%$ DDGS from day 22 to $49-56$ of rearing had no negative effects on production efficiency and meat quality. Moreover, inclusion of DDGS at a level of $25 \%$ allowed decreasing the soyabean meal and wheat contents from 18.0 and $41.6 \%$ in the control feed to 10.0 and $24.1 \%$ in $25 \%$ DDGS, respectively. 


\section{REFERENCES}

Adamski M., Bernacki Z., Kuźniacka J., 2005. The effects of origin and sex on rearing results of ducks from two ancestral paternal strains. Acta Sci. Polon. 4, 13-28

AOAC, 1995. Association of Official Analytical Chemists, Official Methods of Analysis. $15^{\text {th }}$ Edition. Washington DC

Baeza E., 2006. Major trends in research into domestic ducks and recent results concerning meat quality. In: Proceedings of $12^{\text {th }}$ European Poultry Conference, Verona (Italy), p. 8

Bernacki Z., Adamski M., Kuźniacka J., Kokoszynski D., 2006. Comparison of the slaughter values of ducks of different origin to 9 weeks of age. Rocz. Nauk. Zoot. 33, 41-57

Chartrin P., Bernadet M.D., Guy G., Mouro J., Duclos M.J., Baeza E., 2006. Effect of genotype and overfeeding on fat level and composition of adipose and muscle tissue in ducks. Anim. Res. $55,231-244$

Corzo A., Schilling M.W., Loar R.E., Jackson V., Kin S., Radhakrishman V., 2009. The effects of feeding distillers dried grains with solubles on broiler meat quality. Poultry Sci. 88, 432-439

Grau R., Hamm R., 1952. Eine einfache Methode zur Bestimmung der Wasserbindung im Fleisch. Fleischwirtschaft 4, 295-297

Kokoszynski D., Korytkowska H., 2005. Evaluation of meat traits of four duck strains. Acta Sci. Polon. 4, 71-80

Lacin E., Aksu M.I., Macit M., Yildiz A., Karaoglu M., Esenbuga N., Yoruk M.A., 2008. Effect of different raising systems on color and quality characteristics of Turkish Pekin duck meats. S. Afr. J. Anim. Sci. 38, 217-223

Leclercq B., 1998. Specific effects of lysine on broiler production: Comparison with threonine and valine. Poultry Sci. 77, 118-123

Lumpkins B., Batal A., Dale N., 2005. Use of distillers dried grains plus solubles in laying hen diets. J. Appl. Poultry Res. 14, 25-31

Lumpkins B.S., Batal A.B., Dale N.M., 2004. Evaluation of distillers dried grains with solubles as a feed ingredient for broilers. Poultry Sci. 83, 1891-1896

Mazanowski A., Kisiel T., Gornowicz E., 2003. Carcass quality, meat traits and chemical composition of meat in ducks of paternal strains A44 and A55. Anim. Sci. Pap. Rep. 21, 251-263

Mazanowski A., Książkiewicz J., 2004. Comprehensive evaluation of meat traits of ducks from two sire strains. J. Anim. Feed Sci. 13, 173-182

Roberson K.D., 2003. Use of dried distillers' grains with solubles in growing-finishing diets of turkey hens. Int. J. Poultry Sci. 2, 389-393

Roberson K.D., Kalbfleisch J.L., Pan W., Charbeneau R.A., 2005. Effect of corn distiller's dried grains with solubles at various levels on performance of laying hens and egg yolk color. Int. J. Poultry Sci. 4, 44-51

Smulikowska S., Rutkowski A. (Editors), 2005. Nutritional Recommendations and Feed Composition Tables for Poultry (in Poland). The Kielanowski Institute of Physiology Animal Nutrition, Polish Academy of Sciences, Jabłonna (Poland) and Polish Branch of WPSA

Suchý P., Jelínek P., Straková E., Hucl J., 2002. Chemical composition of muscles of hybrid broiler chickens during prolonged feeding. Czech J. Anim. Sci. 47, 511-518

Świątkiewicz S., Koreleski J., 2006. Effect of maize distillers dried grains with solubles and dietary enzyme supplementation on the performance of laying hens. J. Anim. Feed Sci. 15, 253-260

Świątkiewicz S., Koreleski J., 2008. The use of distillers grains with solubles (DDGS) in poultry nutrition. World Poultry Sci. J. 64, 257-265

Wang Z., Cerrate S., Coto C., Yan F., Waldroup P.W., 2007. Utilization of distillers dried grains with solubles (DDGS) in broiler diets using a standardized nutrient matrix. Int. J. Poultry Sci. $6,470-477$ 
Whitney M.H., Shurson G.C., Johnson L.J., Wulf D.M., Shanks B.C., 2006. Growth performance and carcass characteristics of grower-finisher pigs fed high-quality corn destillers dried grain with solubles originating from a modern Mid-western ethanol plant. J. Anim. Sci. 84, 33563363

Witkiewicz K., Kontecka H., Książkiewicz J., 2006. Basic element of eviscerated carcass and chemical composition of pectoral muscle in selected and unselected ducks. Arch. Tierzucht 49, 502-507

Wołoszyn J., Książkiewicz J., Skrabka-Błotnicka T., Haraf G., Biernat J., Kisiel T., 2006. Comparison of amino acid and fatty acid composition of duck breast muscles from five flocks. Arch. Tierzucht 49, 194-204

Ziołecki J., Doruchowski W., 1989. Method of Evaluation the Slaughter Value in Poultry (in Polish). COBRD Publishing. Poznań (Poland) 